\title{
GROWTH AND TRACE METAL CONTENT OF POPLARS PLANTED ON TAILING TREATED WITH MUNICIPAL SOLID WASTE COMPOST ${ }^{1}$
}

\author{
Steven W. Dewar and Michael R. Norland ${ }^{2}$
}

Abstract: Taconite tailing wastes in Minnesota are infertile and difficult to vegetate to meet mineland reclamation standards. Taconite tailing reclamation is a potential use for a municipal solid waste (MSW) compost product. MSW compost is rich in organic compounds, and its application to tailing is likely to improve fertility even though it may increase the level of potentially harmful trace metals. This study assesses tree growth and elemental tissue concentrations of Souixland poplar (Populus deltoides var. Souixland) planted in four $420-\mathrm{m}^{2}$ field plots. Plots were randomly treated with $0,22.4,44.8$, or $89.6 \mathrm{Mg} / \mathrm{ha}$ of MSW compost. After compost application, all plots were fertilized, disced, seeded with a grass-legume mixture, and planted with rooted cuttings of poplar at a 2 by $2.5 \mathrm{~m}$ spacing. After two growing seasons, tree growth was significantly greater where compost was applied. The average growth per live tree was highest in the $89.6 \mathrm{Mg} / \mathrm{ha}$ plot. Average tree height increased from 68.2 to $84.1 \mathrm{~cm}$, a $23 \%$ increase over the control for the highest rate. Survival of trees; however, ranged from 84 to $98 \%$ for the high rate and control, respectively. Ground cover and biomass increased with increasing compost application rates. Analyses of the compost indicated that it met regulations for field application, including PCB's and trace metals. Soils analyses of the tailing after compost application showed higher levels of $\mathrm{N}, \mathrm{P}, \mathrm{S}, \mathrm{Zn}$, and $\mathrm{Cu}$ with increasing application rates. Analyses of poplar leaf tissue revealed slightly higher concentrations of $\mathrm{P}, \mathrm{Zn}, \mathrm{Cu}$, and $\mathrm{Cd}$ for treatments receiving compost. Results suggest that applying compost to coarse tailing will increase the growth of ground cover and poplar trees without adversely affecting the environment.

Additional Key Words: mineland reclamation, taconite, Minnesota, Souixland poplar, Populus deltoides, survival, ground cover, biomass

\section{Introduction}

In northeastern Minnesota there are over 10,000 ha of land covered with taconite tailing waste from eight taconite mining operators. Minnesota's Rules Relating to Mineland Reclamation are administered by the Department of Natural Resources (MDNR) and require that these areas be vegetated to meet a $90 \%$ cover standard after 3 years (MDNR 1980). Coarse-textured tailing areas are particularly difficult to vegetate to meet reclamation requirements. Dependent upon the type of beneficiation process employed, taconite facilities produce tailing either as distinct coarse and fine tailing or as unseparated composite tailing. Coarse tailing are usually utilized to construct a dike which encircles the basin, while a slurry of fine materials is released into the basin interior to settle out of suspension. There are now over 3,000 ha of coarse tailing disposal areas in Minnesota.

The physical and chemical characteristics for taconite taihing do not differ widely among the mine operators (Jordan and Dewar 1985). Taconite tailing do not contain unusual amounts of metals that might inhibit plant growth (Blake 1975). Major plant nutrients of nitrogen and phosphorus are low and have to be applied. In addition, coarse tailing are droughty and lack organic matter essential to maintain soil productivity.

${ }^{1}$ Paper to be presented at the 1994 National meeting of the American Society for Surface Mining and Reclamation, Pittsburgh, PA, April 24-29, 1994.

${ }^{2}$ Steven W. Dewar is Field Supervisor, Mineland Reclamation, Minnesota Department of Natural Resources Division of Minerals, Hibbing, MN 55746; Michael R. Norland is a Soil Scientist, Environmental Technology, Twin Cities Research Center, Bureau of Mines, U.S. Department of the Interior, Minneapolis, MN 55417.

Proceedings America Society of Mining and Reclamation, 1994 pp 203-211

DOI : $10.21000 /$ JASMR94030203

https://doi.org/10.21000/JASMR94030203 
Adding organic matter materials, such as composted municipal garbage, can improve the physical, chemical, and biological properties of soil.

Landfilling solid waste has become less environmentally acceptable and more highly regulated. Amendments to the Minnesota Waste Management Act 1991, list waste reduction, reuse, recycling, and composting as high priorities (Wirth 1991). Composting is a way to transform waste materials into a useful soil amendment. Composting destroys pathogens and converts putrescible organic wastes into a stabilized material, although potentially hazardous levels of trace metals may be introduced into the soil environment and food chain (He et al. 1992).

Composts must reach an acceptable degree of maturity before being marketed as a soil amendment for unrestricted use (MPCA 1991). The degree of stabilization reached by the organic matter in MSW compost appears to be important in determining potential mobility of heavy metals (Leita and De Nobili 1991). Bioavailable trace metals can have strong toxic affects on plants. Incorporating MSW compost into the soil may limit the level of heavy metal solubility. Other notable effects of immature compost on plants is the inhibition of plant seed germination by the production of phytotoxic substances (Wong 1985) and the biological blockage of soil-available N (Jimenez and Garcia 1989).

Marketing a garbage compost product is difficult. The contaminant level, odor, the presence of glass and plastic, and cost can be problems and are of concern to potential users of compost (Stark 1987). Adverse compost characteristics can be controlled by proper upfront planning in the area of quality control. The quality of the compost will determine a particular market for the product. MSW compost products are inherently variable (Walker and O'Donnell 1991, Johnson and Crawford 1993), and the potentially harmful components must be considered before use. Composted MSW is now being used in agriculture, landscaping, and horticulture. Opportunities now exist for solid waste compost use in mineland reclamation (Hart 1968, Stark 1987, Jokela et al. 1990).

Minnesota has over one-third of the operating MSW compost systems in the U.S. (Johnson and Crawford 1993). The research base necessary for composted MSW to enter markets for environmentally acceptable use on mineland reclamation projects in Minnesota is limited. In a companion study (Melchert et al. 1994), MSW compost was applied to a tailing site to examine impacts on water quality and runoff. In recent years other studies have been initiated by the MDNR and the U.S. Bureau of Mines, studying the usefulness of MSW compost as a soil amendment for revegetating coarse taconite tailing (Norland et al. 1991, 1992, 1993). The objective of this paper is to assess tree growth and trace metal concentrations in leaf tissue for trees planted in coarse tailing plots treated with four rates of MSW compost.

\section{Materials and Methods}

The experimental plots are located $10 \mathrm{~km}$ south of Eveleth, MN. Eveleth Mines made a portion of their coarse tailing stockpile available for this research. Eveleth Mines separates coarse materials from the tailing and truck-hauls it to the disposal site. The study area experiences a typical continental climate with wide extremes in temperature between summer and winter, with a mean annual temperature of $4^{\circ} \mathrm{C}$ and precipitation of $688 \mathrm{~mm}$ (Aakre 1975).

The texture of coarse taconite tailing is mostly sand and fine gravel. Analyses of tailing material show it to be alkaline in reaction and low in organic matter, cation-exchange capacity (CEC), soluble salts, and concentrations of nitrate-nitrogen and phosphorus. The chemical and physical properties of the coarse tailing at Eveleth Mines are described in detail elsewhere (Norland et al. 1991).

The research site was prepared by leveling end-dumped coarse tailing piles. Four plots, each measuring 17.5 by $24 \mathrm{~m}$ were randomly assigned a compost treatment. A $5-\mathrm{m}$ buffer zone separated adjacent plots. In 
late April 1992, composted MSW was uniformly applied at the rates of $0,22.4,44.8$, and $89.6 \mathrm{Mg} / \mathrm{ha}$. Fertilizer was applied to all four plots at the rate of $224 \mathrm{~kg} / \mathrm{ha}$ granular diammonium phosphate. The area was then disced so that amendments were incorporated to a depth of $15 \mathrm{~cm}$. Treatment plots were then seeded with a grass-legume cool season mixture that included smooth brome (Bromus inermis Leyss.), red fescue (Festuca rubra L.), perennial ryegrass (Lolium perenne L.), alfalfa (Medicago sativa L.), and buckwheat (Fagopyrum sagittatum Gilib.). Plots were then mulched with hay at the rate of $2 \mathrm{Mg} / \mathrm{ha}$ and crimped in with a disc. Immediately after seeding, the area was hand planted with rooted cuttings of Souixland poplars (Populus deltoides var. Souixland). Individual trees were selected for uniformity prior to planting. Each plot was planted with 84 poplars at a 2 by $2.5 \mathrm{~m}$ spacing.

The compost was obtained from a MSW compost plant located at Mora, MN. The municipal waste it receives comes from a five-county area with a mostly rural population of about 100,000 . More than $50 \%$ of the raw household trash consists of organic waste such as paper, food waste, and plant trimmings and is compostable. At the time the compost used in this experiment was obtained, the processing procedure (East Central Solid Waste Commission 1992) was as follows: corrugated cardboard, newsprint, and plastics were removed, and ferrous metals were separated out by magnet. Remaining materials moved through a shredding, screening, and wet separation process. The wet separators removed glass and other substances. The material biodegraded under controlled moisture and aeration conditions for 2 weeks. The organic material went through a screening process to remove the remaining inorganic material. It then proceeded to the final static aerated pile composting phase. The resulting compost product was ready after $180 \mathrm{~d}$. It was then shredded and screened to separate high-grade from low-grade compost.

The Minnesota Pollution Control Agency (MPCA) administers rules related to solid waste management (MPCA 1991). This includes operating a compost facility and marketing a compost product. Compost distributed as a soil amendment must be registered with the Minnesota Department of Agriculture. Compost produced at a solid waste compost facility must be classified as class I or class II. Class I compost may be distributed for unrestricted use and class II may be distributed on a restricted basis. Class I compost may not be processed with sewage sludge and 1nay contain contaminant levels no greater than shown in table 1. $\mathrm{Cd}, \mathrm{Cu}$, and $\mathrm{Zn}$ came closest to approaching the allowable limit for a class I compost. Class I compost must be stored until the compost is mature and may contain inert materials in quantities (based on particle size) no greater than shown on table 2. A class II compost consists of any compost generated from sewage sludge or fails to meet the class I standards.

The compost facility reported that the compost used on these experimental plots was a class I compost based on the results from analyses completed on the compost just prior to delivery to

Table 1. Comparison of the allowable average contaminant concentrations $(\mathrm{mg} / \mathrm{kg}$ ) for a class I compost (dry weight basis) and sample results from compost used in this experiment.

\begin{tabular}{crc}
\hline & \multicolumn{2}{c}{ Concentration } \\
\cline { 2 - 3 } Contaminant & Allowable & Compost result \\
\hline PCB.............. & 1 & Not detected \\
Cadmium..... & 10 & 8.4 \\
Copper.......... & 500 & 370 \\
Chromium.... & 1,000 & 89 \\
Lead.............. & 500 & 158 \\
Mercury........ & 5 & 1.1 \\
Nickel............ & 100 & 32 \\
Zinc................ & 1,000 & 750 \\
\hline
\end{tabular}

Table 2. Comparison of the allowable quantities of inert materials for a class I compost and sample results from coinpost used in this experiment.

Dry weight percent

\begin{tabular}{llc} 
Particle size & Allowable & Compost result \\
\hline Up to $10 \mathrm{~mm} . . . . .$. & 1.0 & 0.59 \\
Up to $16 \mathrm{~mm} . . . .$. & 2.0 & 1.28 \\
Up to $25 \mathrm{~mm} . . . . .$. & 4.0 & 1.30 \\
\hline
\end{tabular}


the site (tables 1 and 2). Compost material was considered to be mature since it had cured for $180 \mathrm{~d}$ and was not processed with sewage sludge.

Tree survival and heights were measured at the end of the growing season in August 1993. Only the inner 50 trees in each treatment plot were measured. Trees planted on the outside rows and row ends were considered buffer trees and were not measured. Trees were measured from ground level to the terminal bud of the dominant shoot of each living tree. Tree survival and heights were calculated and averaged by treatment.

Elemental tissue concentrations were determined for trees by treatment. Two mature poplar leaves were collected from the upper crown of 20 randomly selected live trees for each treatment and composited. Leaves were dried at $70^{\circ} \mathrm{C}$ and ground in a Wiley mill to pass a 1-mm sieve. Ground tissues were sampled for chemical analysis using ICP (inductively coupled plasma atomic emission spectroscopy) methods.

Ground cover biomass and percent cover were measured in August 1993 for each treatment. Percent ground cover was measured using a systematic point-quadrat sampling method (Raelson and McKee 1982) to estimate cover within a $95 \%$ statistical confidence. Ground cover biomass was estimated by clipping all aboveground plant material from 6 randomly selected $0.11-\mathrm{m}^{2}$ quadrats for each plot. Plant material was dried for $48 \mathrm{~h}$ at $70^{\circ} \mathrm{C}$ and weighed.

Treatment rate effects of composted MSW on tree heights were tested using a one-way analysis of variance (ANOVA). Multiple comparisons of treatment means for tree heights were made using the least significant difference (LSD) test (Steel and Torrie 1980).

\section{Results}

\section{Ground Cover}

A seeded grass-legume ground cover consisting mostly of smooth brome and alfalfa dominated all treatment plots. A minor component of the ground cover included a few scattered weeds found throughout all plots, these included: Indian mustard (Brassica juncea L.), lamb's-quarters (Chenopodium album L.), and ox-eye daisy (Chrysanthemum leucanthemum L.).

Percent ground cover and biomass production differed substantially between MSW compost treatments 15 months after seeding (2 growing seasons). Biomass and percent cover were higher than the control for all compost treatments (table 3). Cover responses increased as MSW compost application rates increased. The highest rate (89.6 $\mathrm{Mg} / \mathrm{ha}$ ) had significantly greater percent cover and biomass than any of the other treatments. Percent cover and biomass compare closely after 2 growing seasons with results from a study (Norland et al. 1992 , 1993) completed earlier using similar application rates of MSW compost. Subsequent findings (Norland et al. 1994) showed that the $90 \%$ cover standard was achieved after 4 seasons.
Table 3. Percent ground cover and biomass production (dry weight) by compost treatment 15 months after application.

\begin{tabular}{ccc}
\hline $\begin{array}{c}\text { Compost } \\
\text { Rate, Mg/ha }\end{array}$ & $\begin{array}{c}\text { Percent } \\
\text { Cover }\end{array}$ & $\begin{array}{c}\text { Biomass, } \\
\mathrm{kg} / \mathrm{ha}\end{array}$ \\
\hline Control... & 22 & 165 \\
$22.4 \ldots \ldots . .$. & 46 & 1,066 \\
$44.8 \ldots \ldots \ldots .$. & 53 & 1,201 \\
$89.6 \ldots . . . . .$. & 80 & 2,553 \\
\hline
\end{tabular}

Table 4. Survival rates by compost treatment for Souixland poplars 15 months after planting.

\begin{tabular}{cc}
$\begin{array}{c}\text { Compost } \\
\text { rate, } \mathrm{Mg} / \mathrm{ha}\end{array}$ & $\begin{array}{c}\text { Percent } \\
\text { survival }^{1}\end{array}$ \\
\hline Control... & 98 \\
$22.4 \ldots \ldots . .$. & 86 \\
$44.8 \ldots \ldots . .$. & 96 \\
$89.6 \ldots \ldots . .$. & 84 \\
\hline
\end{tabular}

${ }^{1}$ Average of 50 trees. 


\section{Tree Survival and Growth}

Trees suffered little mortality on all treatments 15 months after planting (table 4). Tree survival ranged from 84 to $98 \%$ for the high and control rates, respectively. A slightly higher mortality rate for the compost treatments may be attributable to greater amounts of ground cover competing with trees. Competing vegetation can lower the survival and growth of newly planted trees (Smith 1962). Survival rates above $80 \%$ are considered good for new tree plantings.

Applications of MSW compost significantly increased the growth of poplars for all treatment rates (table 5). Mean tree heights ranged from 68.2 to $84.1 \mathrm{~cm}$ for the control and highest compost rate, respectively. Increases in tree growth from compost application ranged from $16 \%$ to $23 \%$ over the control (fig. 1). Tree growth increased with increasing rates of compost.

A leaf blight developed on most of the trees during July 1993 and may have reduced the growth of infected trees. The fungi for this disease (Marssonia populi) develop in wet weather. The spring and summer of 1993 had an above average amount of rainfall. Although trees are seldom killed by the fungi involved, their growth rate can be reduced (French and Cowling 1975).

\section{Soil and Tissue Chemistry}

Analyses of the soils and leaf tissue indicated there were changes in soil and leaf tissue chemistry with increasing rates of MSW compost applications (tables 6 and 7). Metals and PCB's can have toxic impacts on plant or animal life. Elevated levels of trace metal contaminants of $\mathrm{Zn}$ and $\mathrm{Cu}$ were detected in both the soils and tissue analyses with increasing rates of compost. Higher levels of $\mathrm{Cd}$ were detected in leaf tissue. Cd was not tested in the soils analyses. Since PCB's were not detected in the compost it was not analyzed in the soils or tissue. Concentration levels of $\mathrm{Pb}$ and $\mathrm{Cr}$ in the leaf tissue was at or near detection limits. Compost analyses from table 1, showed that $\mathrm{Cd}, \mathrm{Cu}$, and $\mathrm{Zn}$ come closest to approaching the allowable limit for a class I compost. Elevated levels of $\mathrm{Zn}, \mathrm{Cu}$, and $\mathrm{Cd}$ may be of some concern; however, they are of less concern when incorporated into alkaline tailing. These metals move less readily in an alkaline soil and tend to revert to more unavailable forms over time (Crawford and Johnson 1988).

Potentially harmful trace metals did not limit plant growth. For all treatment rates, concentrations of $\mathrm{Zn}$
Table 5. Multiple paired comparisons between mean tree heights for all compost treatments using the LSD test.

\begin{tabular}{cl}
\hline $\begin{array}{c}\text { Compost } \\
\text { rate, } \mathrm{Mg} / \mathrm{ha}\end{array}$ & $\begin{array}{l}\text { Mean tree } \\
\text { height, } \mathrm{cm}^{1}\end{array}$ \\
\hline Control... & $68.2 \mathrm{a}$ \\
$22.4 \ldots \ldots . .$. & $79.2 \mathrm{~b}$ \\
$44.8 \ldots \ldots . . .$. & $80.6 \mathrm{bc}$ \\
$89.6 \ldots \ldots . .$. & $84.1 \mathrm{c}$ \\
\hline
\end{tabular}

${ }^{1}$ Average of 50 trees. Means followed by the same letter are not significantly different, $\mathrm{LSD}_{.05}=4.2 \mathrm{~cm}$.

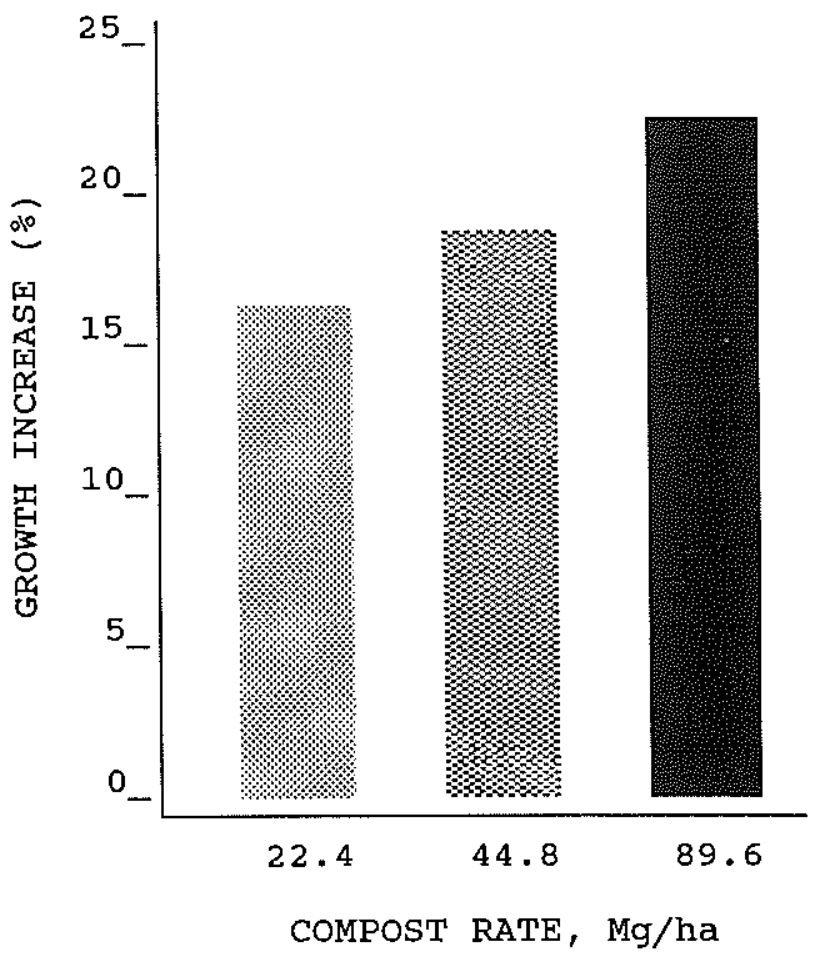

Figure 1. Percent increase in growth of Souixland poplars for each compost treatment as compared to the control treatment. 
and $\mathrm{Cu}$ in the tailing soil were within the normal range found in soils (Allaway 1968). Plant tissue values for $\mathrm{Zn}, \mathrm{Cu}$, and $\mathrm{Cd}$ were below toxic levels (Melsted 1973) for all treatments. This is substantiated by the higher amounts of ground cover and tree growth with increasing compost rates reported earlier.

Compost applications tended to increase soil fertility, as indicated by a considerable increase in $\mathrm{CEC}$ and extractable $\mathrm{P}$ with increasing rates (table 7). Levels of extractable $P$ above $15 \mathrm{mg} / \mathrm{kg}$ are sufficient for grass-legume stands (Jokela et al. 1981). Higher levels of organic matter were detected at the high rate. There was no substantial change in the $\mathrm{pH}$, soluble salts, and mitrate-nitrogen. It is unlikely that increases in extractable $\mathrm{Zn}$ and $\mathrm{Cu}$ contributed significantly to increases in growth.

\section{Discussion}

Compost incorporated into coarse-textured soils may improve the physical and chemical properties of soil (Pritchett and Fisher 1987). Previous research (Norland et al. 1994) near this site reported increases in percent ground cover and biomass using similar rates of MSW compost. The $90 \%$ cover standard was achieved on comparable compost treatments after 4 growing seasons, a similar result can be expected for this study. Garbage compost incorporated into sandy soil sustained the growth of pine trees for $16 \mathrm{yr}$ without long-term deleterious effects to the ecosystem (Jokela et al. 1990). Trace metals contained in MSW composts will revert to less soluble forms upon incorporation, thus reducing the likelihood of plant uptake or leaching losses. In a companion study (Melchert et al. 1994), on a tailing site treated similarly with MSW compost, initial sampling indicated that nitrates were the only chemical that exceeded water quality standards. Nitrates decreased after subsequent sampling and are expected to diminish further.

Mining companies have had considerable difficulty meeting vegetation standards on coarse tailing sites. The addition of organic matter from compost may help sustain long-term plant growth on coarse tailing. Higher levels of organic matter can improve the water-holding capacity and maintain plant growth during dry periods. Taconite tailing are deficient in plant-available P. MSW compost applications can supply sufficient levels of P. The nutrient-supplying characteristic of compost may be similar to slow-release fertilizers.

The variability of MSW compost products is a problem (Walker and O'Donnell 1991). Levels of nutrients and contaminants can vary significantly among compost operations and between batches (Johnson and Crawford 1993). MSW compost must meet an acceptable degree of maturity. The use of immature compost can cause 
$\mathrm{N}$ deficiencies, inhibition of seed germination, and an increase in the solubility of heavy metals. The compost used in this study was placed on the storage pad for $180 \mathrm{~d}$, which is considered ample time for decomposition to occur to produce a mature and stable compost product. However, there was some odor associated with the compost which can be an indication of anaerobic conditions. Anaerobic conditions will inhibit the composting process. A conversation with the compost operator indicated that the compost piles may not have been "turned" enough to provide sufficient aeration for favorable composting conditions. Even though the compost may not have fully cured, no toxic effects on plant growth were noted from compost applications. MSW compost applied to tailing increased plant growth at increasing application rates. Compost quality is of primary concern for agricultural, landscaping, and horticultural uses. It may not be as important for use in reclamation. A lesser grade of MSW compost may be acceptable for reclamation use, particularly when mining sites are located away from populated areas. Developing standards of acceptance for MSW compost products should receive careful attention.

There is widespread agreement that municipal wastes should be recycled and reused. The manufacturing of compost from the biodegradable portion of solid waste is gaining attention as an alternative to landfilling. Interest in composting is growing in Minnesota, largely because of increasing land disposal costs (Wirth 1991). Composting is becoming cost competitive with other solid waste management alternatives. Opportunities exist in Minnesota for MSW compost use on mineland reclamation sites, although with a haul distance of over 150 $\mathrm{km}$ from the nearest compost facility, it may not be feasible.

The potential for using MSW compost on coarse taconite tailing sites is significant. There are over 3,000 la of coarse tailing that could be reclaimed to meet reclamation standards using a MSW compost product. This could utilize over $270,000 \mathrm{Mg}$ of composted MSW. The largest compost facility in Minnesota produces about $75 \mathrm{Mg}$ /day of class I compost. This facility would have to produce compost for $10 \mathrm{y}$ to satisfy the potential demand for all existing coarse tailing reclamation sites.

\section{Conclusions}

Using composted garbage on coarse tailing reclamation sites should be more environmentally acceptable and economically feasible than landfilling or other methods of disposal. The results of present and other studies, reveal that MSW compost can improve plant growth on infertile soils considerably.

MSW compost applications improved the soil properties of taconite tailing and increased the growth of ground cover and Souixland poplar trees. Trace metals introduced into the soil environment were not toxic or limiting to plant growth at application rates up to $89.6 \mathrm{Mg} / \mathrm{ha}$.

Revegetation work on coarse tailing sites is not likely to succeed to meet reclamation standards without some organic amendment addition. MSW compost is potentially an inexpensive source of organic material for reclamation if a compost facility is located nearby. The use of composted MSW as a soil amendment is an appealing metliod for improving the growth of ground cover and trees on coarse taconite tailing reclamation sites without adversely affecting the environment.

\section{References}

Aakre, R. B. 1975. Ten year supplement to fifty years of weather in North Central Minnesota. Univ. of MN, Agric. Exp. Station, Misc. Rep. 68.

Allaway, W. H. 1968. Agronomic controls over environmental cycling of trace metals. Adv. Agron. 20:235-271. http://dx.doi.org/10.1016/S0065-2113(08)60858-5

Blake, G. R. 1975. Appraisal of taconite tailings as a soil medium for plants. Draft Environmental Impact Statement. Barton- Aschman Assoc., Inc. p. 108-117. 
Crawford, S. L. and G. E. Johnson. 1988. The environmental hazards of metals and PCB's in compost. Session XXVI. In Proceedings of the Seventh National Recycling Congress. (St. Paul, MN, September 27-30, 1988).

East Central Solid Waste Commission. 1992. Materials recovery and composting facility fact sheet. Daneco, Inc. $4 \mathrm{p}$.

French, D. W. and E. B. Cowling. 1975. Forest and shade tree pathology. Univ. of MN. 258 p.

Hart, S. A. 1968. Solid waste management/composting: European activity and American potential. U.S. Public Health Serv. Publ. 1826. 40 p.

He, X. T., S. J. Traina, and T. J. Logan. 1992. Chemical properties of municipal solid waste composts. J. Environ. Qual. 21:318-329.

http://dx.doi.org/10.2134/jeq1992.00472425002100030003x

Jimenez, E. I. and V. P. Garcia. 1989. Evaluation of city refuse compost maturity: A review. Biological Wastes 27:115-142.

http://dx.doi.org/10.1016/0269-7483(89)90039-6

Johnson, G. E. and S. L. Crawford. 1993. Evaluating compost quality. Resource Recycling. 12:50-54.

Jokela, E. J., W. H. Smith, and S. R. Colbert. 1990. Growth and elemental content of slash pine 16 years after treatment with garbage composted with sewage sludge. J. Environ. Qual. 19:146-150.

http://dx.doi.org/10.2134/jeq1990.00472425001900018022x

Jokela, W. E., W. E. Fenster, C. J. Overdahl, C. A. Simkins, and J. Grava. 1981. Guide to computer programmed soil test recommendations for field crops in Minnesota. Ext. Bull. 416. Univ. of MN. 30 p.

Jordan, J. E. and S. W. Dewar. 1985. Vegetation characterization of a taconite tailing basin in Minnesota. p. 249-254. In Proceedings of the Symposium on Surface Mining, Hydrology, Sedimentology, and Reclamation. (Lexington, KY, December 9-13, 1985).

Leita, L. and M. De Nobili. 1991. Water-soluble fractions of heavy metals during composting of municipal solid waste. J. Environ. Qual. 20:73-78.

http://dx.doi.org/10.2134/ jeq1991.004724250020000-10012x

Melchert, G. D., P. E. Eger, Z. Kassa, and S. W. Dewar. 1994. Reclaiming coarse taconite tailing with municipal solid waste compost. In Proceedings National Meeting of the American Society for Surface Mining and Reclamation. (Pittsburgh, PA, April 25-29, 1994).

http://dx.doi.org/10.21000/JASMR94030175

Melsted, S. W. 1973. Soil-plant relationships. p. 121-128. In Proceedings on Recycling Municipal Sludge and Effluents on Land. (Champaign, IL, 1973).

Minnesota Department of Natural Resources. 1980. Mineland reclamation rules, ch. 6130. p. 5694-5717.

Minnesota Pollution Control Agency. 1991. Solid waste management rules, ch. 7035.2835.

Norland, M. R., D. L. Veith, and S. W. Dewar. 1991. Initial vegetative cover on coarse taconite tailing using organic amendments on Minnesota's Mesabi Iron Range. p. 263-277. In Proceedings National Meeting of the American Society for Surface Mining and Reclamation. (Durango, CO, May 14-17, 1991).

http://dx.doi.org/10.21000/JASMR91010263

Norland, M. R., D. L. Veith, and S. W. Dewar. 1992. Vegetation response to organic soil amendments on coarse taconite tailing. p. 341-360. In Proceedings National Meeting of the American Society for Surface Mining and Reclamation. (Duluth, MN, June 14-18, 1992).

http://dx.doi.org/10.21000/JASMR92010341 
Norland, M. R., D. L. Veith, and S. W. Dewar. 1993. Standing crop biomass and cover on amended coarse taconite iron ore tailing, p. 385-415. In Proceedings National Meeting of the American Society for Surface Mining and Reclamation. (Spokane, WA, May 16-19, 1993).

http://dx.doi.org/10.21000/JASMR93010385

Norland, M. R., D. L. Veith, and S. W. Dewar. 1994. Revegetation of coarse tailings. University of Minnesota Mining Symposium. (Duluth, MN, January 20, 1994).

Pritchett, W. L. and R. F. Fisher. 1987. Properties and management of forest soils. Wiley, New York. 494 p.

Raelson, J. V. and G. W. McKee. 1982. Measurement of plant cover to evaluate revegetation success. Agronomy Series 67, Department of Agronomy, PA State Univ. 45 p.

Smith, D. M. 1962. The practice of silviculture. Wiley, New York. 578 p.

Stark, S. A. 1987. Agricultural use of solid waste compost products. Soil Sci. Dep., Univ. of MN. 8 p.

Steel, R. G. and J. H. Torrie. 1980. Principles and procedures of statistics. McGraw-Hill, New York. 633 p.

Walker, J. M. and M. J. O'Donnell. 1991. Comparative assessment of MSW compost characteristics. Biocycle 32(8):65-69.

Wirth, R. 1991. Introduction to composting. MN Pollution Control Agency. 38 p.

Wong, M. H. 1985. Phytotoxicity of refuse compost during the process of maturation. Environ. Pollut. Ser. A. p. 159-174. 